one of a very few with the kind of strong leadership that has made it a major player. Government policy has kept most in a subordinate position, where it is extremely difficult to compete with the second-tier colleges of public universities, and few are permitted to offer degree programs.

\section{Demand-Absorbing Private Institutions in Mexico}

\section{Juan Carlos Silas}

Juan Carlos Silas is a PROPHE Affiliate and professor in the Department of Education at the Universidad de Monterrey, Monterrey, Mexico. E-mail: jsilas@udem.edu.mx.

IHE devotes a column in each issue to a contribution from PROPHE, the Program for Research on Private Higher Education, headquartered at the University at Albany. See http://www.albany.edu/.

Mexican higher education is very dynamic and has I reshaped itself due to demographic, social, and political changes. The expansion of the country's most-rapid-growing subsector has included dramatic growth of enrollments and institutions, and diversification of institutions.

\section{The Demand-Absorbing Subsector}

The term and basic characteristics of "demand-absorbing" were introduced in Daniel Levy's pioneering study two decades ago. He found demand-absorbers to be academically flimsy, narrow, usually small, and not seeking prominence in the academic disciplines-quite nonelite. Compared to other institutions they are tuition based (though they charge less than other privates do), seldom receive donations, survive largely by hiring professors from public institutions interested in additional income, and hold operational costs to a minimum.

Some common elements foster the start-up of demandabsorbing institutions in Mexico and many other countries: a large unsatisfied demand from secondary education diplomaholders trying to further their education, insufficient regulation for limiting the development of lower-quality institutions, and financial constraints preventing public institutions from enhancing their intake of qualified students. It follows that in a context of high demand, lax regulation, and financial constraints, both the educational providers and students seeking an available place are forced to look for different options. The result of this quest includes the establishment of institutions offering vocational-like and affordable education that provides students from lower socioeconomic backgrounds the opportu- nity to obtain a college degree.

\section{The Growth of the Subsector}

Empirical evidence links most demand-absorbing institutions to the diversification and growth of the private sector, which now contains about I6 percent of total Mexican enrollment. The diversification of institutions, models, and programs is related to the demographic pressure and a paradigm change about the functions of higher education that seems to give higher value to the development of professional and vocational skills linked to the job market. In the new programs and institutions, instruction does not measure up with the idea of university-like education and rather than professional educators requires practitioners knowledgeable about the practical profession and prepared to polish job-related skills. Demandabsorbing institutions appeal to students who select their institution and program of study according to their calculation of lesser perceived effort, opportunities for staying active in the labor market while studying, and expected return of time and money invested.

In the last 25 years, nonuniversity private higher education institutions have mushroomed, another trend found in other countries as well. One form occurs where organizations focus their programs on a specific area (communications sciences, psychology and psychotherapy, or gastronomy). A second form occurs where smaller institutions emerge, usually created by entrepreneurs and with a geographical coverage circumscribed to specific urban areas. These institutions offer traditional programs at a low cost and are usually directed to the service sec-

Some common elements foster the start-up of demand-absorbing institutions in Mexico and many other countries: a large unsatisfied demand from secondary education diploma-holders..

tor of the economy. In Mexico and beyond, this expansion seems to be known and tolerated by national governments and educational systems as a way to provide low-income students with access to higher education.

\section{The Current Demand-Absorbing Subsector}

Data from the 2005/06 school year shows 87 percent of the private higher education institutions in Mexico constitute demand-absorbing ones. With 328,803 undergraduates they enroll almost half (48.5\%) the students registered in the private sector and 16 percent of the national enrollment. Most of these institutions are small; 40 percent of them enroll roo students or fewer. However, one can find eight institutions enrolling more than 5,000 students-one of which reports having more than 16,000 students at 33 sites.

Mexico's contemporary demand-absorbing subsector relies on noncontract teaching personnel and a strong focus on licen- 
ciatura (four-year undergraduate degrees). Representing 65 percent of the 777 total demand-absorbing ones, 506 institutions report Ioo percent "hourlies" (part-timers) as the composition of their teaching staff. Seventy-nine percent of the institutions offer only licenciatura, while the remaining 2I percent of institutions offer licenciatura plus some master's degrees. Few of these degrees require a costly infrastructure for laboratories or technology, and most of them are in the fields of administrative sciences, humanities, and education, or computer sciences, with aspirations of a fast immersion into the job market.

\section{African Higher Education: Projecting the Future Damtew Teferra}

Damtew Teferra is Director for Africa and the Middle East at the Ford Foundation International Fellowships Program based in New York. He directs the International Network for Higher Education in Africa. E-mail: teferra@bc.edu.

$T^{n}$ the last decade, higher education in Africa has seen policy 1 shifts in favor of higher education, massive demand and major growth in providers, and unprecedented progress in information and communications technologies. However, the region has also faced large numbers of unemployed and unemployable graduates, uncertainty due to international regimes such as the General Agreement on Trade in Services (GATS), diminishing faculty numbers, and massive brain drain.

\section{EMANCIPATION AND REVITALIZATION}

African higher education survived under the shadow of international sanctions for several decades following the rate-ofreturn study supported by the World Bank in mid-ig8os that defined higher education as a luxury the continent could ill afford. The World Bank dropped loan requests for higher education development on the continent. Other international development partners and major philanthropic organizations, even some considered to be fiercely independent, followed the same policy track, dropping higher education from their development agenda. African governments themselves neglected universities largely due to external influence.

With the publications of Higher Education and Developing Countries: Peril and Promise (World Bank, 2000) and Constructing Knowledge Societies (World Bank, 2002), which affirmed the role of higher education in the globalized world, the World Bank's position has shifted in favor of higher educa- tion, in effect emancipating the system in the region. This approach has created the opportunity for the bank, other development partners, and respective governments to revitalize and expand the higher education system on the continent. One may mark this major policy shift as the most important development in African higher education landscape over the last decade.

\section{Private Expansion: Public Influence}

In many countries, upgraded and brand-new public institutions have experienced hikes in student enrollment. Even more so, the growth of private institutions has been phenomenal. For example, in Ethiopia, where virtually no such institution existed a decade ago, over 60 operate now. There are 18 in Kenya, 20 in Tanzania, and 32 in Nigeria. One of the most remarkable developments in the continent's higher education system is the mushrooming of private colleges. However, the demand for access is still far from fulfilled, with a total 5 percent enrollment in the region.

As the liberalized global economic policies encouraged the growth of private institutions on the continent, the expansion had a direct and indirect impact on the funding of public higher education institutions. In response, the trend provided public institutions an impetus for practicing several cost-sharing initiatives that some observers dub as the "privatization" of public institutions. The taboo regarding revenue generation has eased up, and controversies surrounding cost sharing have

As access to higher education is rapidly expanding in the region, quality has emerged as a growing concern for stakeholders-students, parents, guardians, employers, and governments.

been muted. These developments, however, are being re-evaluated as issues of equity, quality, and access are being raised. Even more so, the private expansion has fostered negligence of public higher education expansion by financially strapped governments, limiting their support to the subsector.

Numerous threads are shared among the recently established nonsectarian private institutions in the region-and around the world. These institutions are generally smaller in size, limited to programs of popular demand, market oriented, and fee and tuition dependent. They often rely on staff from major public institutions, largely part-timers, virtually none of whom pursue research; postgraduate programs are rarely offered.

Private higher education institutions, especially those dependent on tuition and fees are generally unstable, precarious, and resource challenged. Yet, private higher education providers in the region that are established, funded, and run by religious groups are growing in number and significance. 